\title{
Plant morphology, physiological characteristics, accumulation of secondary metabolites and antioxidant activities of Prunella vulgaris L. under UV solar exclusion
}

\author{
Yuhang Chen ${ }^{1,2,3^{*}{ }^{+}}$, Xuerong Zhang ${ }^{2,4+}$, Qiaosheng Guo ${ }^{2 *}$, Liping Cao ${ }^{1}$, Qin Qin ${ }^{1}$, Chen Li ${ }^{1}$, Miao Zhao ${ }^{1}$ \\ and Wenming Wang ${ }^{3}$
}

\begin{abstract}
Background: Prunella vulgaris L. has been an important medicinal plant for the treatment of thyroid gland malfunction and mastitis in China for over 2000 years. There is an urgent need to select effective wavelengths for greenhouse cultivation of $P$. vulgaris as light is a very important factor in $P$. vulgaris growth. Here, we described the effects of natural light (control) and UV solar exclusion on the morphological and physiological traits, secondary metabolites contents and antioxidant activities of $P$. vulgaris.

Results: The results showed that UV solar exclusion resulted in remarkable alterations to morphological and biomass traits; significantly reduced the chlorophyll a, chlorophyll b and total chlorophyll contents; significantly enhanced the ratio of chlorophyll a to b; and significantly increased the carotenoid and anthocyanin contents in P. vulgaris. UV solar exclusion significantly increased the catalase (CAT) and peroxidase (POD) activities, increased superoxide dismutase (SOD) and ascorbate peroxidase (APX) activities and slightly decreased the glutathione (GSH) content. UV solar exclusion significantly increased the soluble sugar and $\mathrm{H}_{2} \mathrm{O}_{2}$ contents and increased the soluble protein content but significantly decreased the proline content and slightly decreased the MDA content. The secondary metabolite contents (total phenolics, rosmarinic acid, caffeic acid, hyperoside, ursolic acid and oleanolic acid) and in vitro antioxidative properties (DPPH. and ABTS. ${ }^{+}$scavenging activities) were significantly increased in P. vulgaris spicas under UV solar exclusion. Additionally, the total polysaccharide and total flavonoids contents were slightly increased by UV solar exclusion. The salviaflaside content was significantly reduced by UV solar exclusion.
\end{abstract}

Conclusion: Our study demonstrated that $P$. vulgaris activates several antioxidant defence systems against oxidative damage caused by UV solar exclusion.

Keywords: Prunella vulgaris L., UV exclusion, Physiological traits, Secondary metabolites, Antioxidants

\footnotetext{
*Correspondence: chenyuhang221@126.com; gqs@njau.edu.cn

${ }^{\dagger}$ Yuhang Chen and Xuerong Zhang contributed equally to this work

${ }^{1}$ College of Pharmaceutical Sciences, Chengdu Medical College,

Chengdu 610500, Sichuan, China

${ }^{2}$ Institute of Chinese Medicinal Materials, Nanjing Agricultural University,

Nanjing 210095, Jiangsu, China

Full list of author information is available at the end of the article
}

(c) The Author(s) 2019. This article is distributed under the terms of the Creative Commons Attribution 4.0 International License (http://creativecommons.org/licenses/by/4.0/), which permits unrestricted use, distribution, and reproduction in any medium, provided you give appropriate credit to the original author(s) and the source, provide a link to the Creative Commons license, and indicate if changes were made. The Creative Commons Public Domain Dedication waiver (http://creativecommons.org/ publicdomain/zero/1.0/) applies to the data made available in this article, unless otherwise stated. 


\section{Background}

Prunella vulgaris L. (Labiatae) is an important medicinal plant that is typically found in Europe and Asia [1,2]. Dried spicas of $P$. vulgaris, Prunellae Spica, are a standard medicinal material in the Chinese pharmacopoeia [3] and is occasionally used for the treatment of thyroid gland malfunction, mastitis, pulmonary tuberculosis, infectious hepatitis, and hypertension [4]. In recent years, demand for Prunellae Spica has increased steadily due to its medicinal importance. Approximately five million kilograms of Prunellae Spica is required every year for Chinese patent medicine [5]. In addition to its pharmaceutical industrial use, the dried spicas of $P$. vulgaris are manufactured as a functional herbal tea, the fresh leaves of $P$. vulgaris seedlings are consumed as a vegetable dish in southeast China and P. vulgaris plants are often used as ornamental plants for urban greenery in southern China [6-8].

Phenolic acids, flavonoids, triterpenes and polysaccharides are the most abundant types of active ingredients in P. vulgaris [9]. Rosmarinic acid and caffeic acid are the major phenolic components in Prunellae Spica [10,11] and act as photo-protective agents to scavenge ROS produced by UV-B radiation [12-14]. Salviaflaside, formed by the intermolecular condensation of two phenylpropanoid derivative molecules, is an indicator component in Prunellae Spica [4]. Hyperoside is another major flavonoid component of $P$. vulgaris that mitigates oxidative damage due to ROS production [15]. Of the triterpenes, ursolic acid and oleanolic acid are the most prevalent in P. vulgaris and possess antioxidant, anti-allergic, antiinflammatory and antitumour functions $[16,17]$. In addition, $P$. vulgaris polysaccharides have been reported as potential antioxidant and immunomodulatory agents for complementary medicine [18].

Additionally, studies using specific filters for solar UV exclusion to remove UV radiation (280-400 nm) have generally focused on the impacts of UV-B on plant growth and morphology [19]. Recent studies in India and Brazil have reported that solar UV exclusion significantly affects the photosynthesis, growth, yield and quality of some crop and medicinal plants [20,21]. These studies have revealed the importance of specific wavelengths for the cultivation of crop and medicinal plants.

Previous studies have described the influence of abiotic factors, such as heavy metals [22], drought [23], UV-B radiation [15], different soil nutrient concentrations $[24,25]$ and different spectral lights [26], on the productivity, physiological, and quality of $P$. vulgaris. However, no study in the literature has investigated the effects of UV solar exclusion on the growth and quality of $P$. vulgaris. Therefore, it is necessary to explore the effects of UV solar exclusion on the morphological traits, photosynthetic pigment contents, cellular defence system products, secondary metabolite biosynthesis, and antioxidant activities of ethanol extracts of $P$. vulgaris.

\section{Results \\ Morphology and biomass}

The morphological and biomass characteristics of P. vulgaris were studied under UV solar exclusion (Table 1). Branch number per plant, stem weight and whole-plant weight under UV solar exclusion were significantly increased compared to the results obtained with control treatment. Spica number per plant, spica length, root weight, leaf weight and spica weight under UV solar exclusion were increased with no significance compared to the results obtained with control treatment. Spica width was decreased under UV solar exclusion, but both differences were not significant.

\section{Photosynthetic pigment and anthocyanin contents}

The photosynthetic pigment and anthocyanin contents were studied in $P$. vulgaris under UV solar exclusion (Table 2). The chlorophyll a, chlorophyll b and total chlorophyll contents were significantly reduced by UV solar exclusion. Meanwhile, the ratio of chlorophyll $a$ and $b$ and the carotenoid and anthocyanin contents were significantly enhanced by UV solar exclusion, but the ratio of chlorophyll $a$ and $b$ under UV solar exclusion was not significant.

\section{Antioxidant systems}

The POD, CAT, SOD and APX activities and GSH content were studied in $P$. vulgaris under UV solar exclusion (Table 3). The POD, CAT, SOD and APX activities were increased under UV solar exclusion, and the difference between POD and CAT was significantly increased compared to the results obtained with control treatment. By contrast, the GSH content slightly decreased under UV solar exclusion.

\begin{tabular}{|c|c|c|}
\hline Characteristics & Control & UV solar exclusion \\
\hline Branch number per plant & $2.3 \pm 2.1 \mathrm{~b}$ & $5.2 \pm 0.9 \mathrm{a}$ \\
\hline Spica number per plant & $8.7 \pm 3.3 \mathrm{ab}$ & $13.0 \pm 6.0 \mathrm{a}$ \\
\hline Spica length (cm) & $4.32 \pm 1.01 \mathrm{a}$ & $4.86 \pm 0.98 a$ \\
\hline Spica width (cm) & $1.21 \pm 0.12 \mathrm{a}$ & $1.16 \pm 0.11 \mathrm{a}$ \\
\hline Root weight (g plant ${ }^{-1}$ ) & $0.32 \pm 0.15 \mathrm{a}$ & $0.50 \pm 0.21 \mathrm{a}$ \\
\hline Stem weight (g plant ${ }^{-1}$ ) & $1.71 \pm 0.40 b$ & $2.84 \pm 0.81 \mathrm{a}$ \\
\hline Leaf weight (g plant ${ }^{-1}$ ) & $1.98 \pm 0.79 \mathrm{ab}$ & $2.87 \pm 1.40 \mathrm{a}$ \\
\hline Spica weight (g plant ${ }^{-1}$ ) & $1.30 \pm 0.50 \mathrm{ab}$ & $1.73 \pm 0.73 \mathrm{a}$ \\
\hline Whole plant weight (g plant ${ }^{-1}$ ) & $5.42 \pm 1.37 b$ & $8.10 \pm 1.72 \mathrm{a}$ \\
\hline
\end{tabular}

Each value is presented as the mean $\pm S D(n=10)$. Different letters in lines indicate a significant difference at $p<0.05$ 
Table 2 The effects of UV solar exclusion on the photosynthetic pigment and anthocyanin contents of $P$. vulgaris leaves

\begin{tabular}{lll}
\hline Pigment parameter & Control & UV solar exclusion \\
\hline Chlorophyll a $\left(\mathrm{mg} \mathrm{g}^{-1}\right)$ & $1.60 \pm 0.12 \mathrm{a}$ & $1.29 \pm 0.02 \mathrm{~b}$ \\
Chlorophyll b $\left(\mathrm{mg} \mathrm{g}^{-1}\right)$ & $1.24 \pm 0.24 \mathrm{a}$ & $0.84 \pm 0.01 \mathrm{~b}$ \\
Total chlorophyll $\left(\mathrm{mg} \mathrm{g}^{-1}\right)$ & $2.84 \pm 0.36 \mathrm{a}$ & $2.13 \pm 0.03 \mathrm{~b}$ \\
Chlorophyll a/b ratio & $1.31 \pm 0.17 \mathrm{ab}$ & $1.54 \pm 0.01 \mathrm{a}$ \\
Carotenoids $\left(\mathrm{mg} \mathrm{g}^{-1}\right)$ & $0.06 \pm 0.04 \mathrm{~b}$ & $0.10 \pm 0.00 \mathrm{a}$ \\
Anthocyanin $\left(\mathrm{A} \mathrm{g}^{-1} \mathrm{FW}\right)$ & $2.67 \pm 0.11 \mathrm{~b}$ & $2.88 \pm 0.03 \mathrm{a}$ \\
\hline
\end{tabular}

Each value is presented as the mean $\pm S D(n=3)$. Different letters in lines indicate a significant difference at $p<0.05$

Table 3 The effects of UV solar exclusion on the POD, CAT, SOD and APX activities and GSH content in $P$. vulgaris leaves

\begin{tabular}{|c|c|c|}
\hline Antioxidant system & Control & UV solar exclusion \\
\hline POD activity ( $U \mathrm{mg}^{-1}$ proteins) & $78.48 \pm 3.31 b$ & $112.73 \pm 21.37 \mathrm{a}$ \\
\hline CAT activity ( $U \mathrm{mg}^{-1}$ proteins) & $38.09 \pm 7.22 b$ & $53.06 \pm 7.28 \mathrm{a}$ \\
\hline SOD activity ( $U \mathrm{mg}^{-1}$ proteins) & $49.12 \pm 9.36 a$ & $53.91 \pm 14.11 \mathrm{a}$ \\
\hline APX activity ( $U \mathrm{mg}^{-1}$ proteins) & $0.62 \pm 0.10 \mathrm{a}$ & $0.80 \pm 0.07 a$ \\
\hline GSH content ( $\mathrm{mg} \mathrm{g}^{-1}$ proteins) & $95.79 \pm 4.21 \mathrm{a}$ & $90.39 \pm 1.68 \mathrm{a}$ \\
\hline
\end{tabular}

Each value is presented as the mean $\pm S D(n=3)$. Different letters in lines indicate a significant difference at $p<0.05$

Table 4 The effects of UV solar exclusion on the soluble protein, soluble sugar, proline, $\mathrm{H}_{2} \mathrm{O}_{2}$ and MDA contents in $P$. vulgaris leaves

\begin{tabular}{|c|c|c|}
\hline Oxidative stress indicators & Control & UV solar exclusion \\
\hline Soluble protein $\left(\mathrm{g} \mathrm{L}^{-1} \mathrm{FW}\right)$ & $0.25 \pm 0.01 \mathrm{a}$ & $0.27 \pm 0.04 a$ \\
\hline Soluble sugar (mg mg $\mathrm{mg}^{-1}$ proteins) & $7.68 \pm 0.30 b$ & $9.26 \pm 0.57 a$ \\
\hline Proline ( $\left.\mu \mathrm{g} \mathrm{g}{ }^{-1} \mathrm{FW}\right)$ & $34.40 \pm 1.20 \mathrm{a}$ & $29.42 \pm 1.33 b$ \\
\hline $\mathrm{H}_{2} \mathrm{O}_{2}$ (mmol g ${ }^{-1}$ proteins $)$ & $43.25 \pm 1.66 b$ & $61.14 \pm 0.59 a$ \\
\hline $\mathrm{MDA}$ (nmol $\mathrm{mg}^{-1}$ proteins) & $44.01 \pm 7.11 \mathrm{a}$ & $41.33 \pm 5.07 a$ \\
\hline
\end{tabular}

Each value is presented as the mean $\pm S D(n=3)$. Different letters in lines indicate a significant difference at $p<0.05$

Soluble protein, soluble sugar, proline, $\mathrm{H}_{2} \mathrm{O}_{2}$, and MDA contents

The soluble protein, soluble sugar, proline, $\mathrm{H}_{2} \mathrm{O}_{2}$, and MDA contents were studied in $P$. vulgaris under UV solar exclusion and supplemental UV-B radiation (Table 4). The soluble sugar and $\mathrm{H}_{2} \mathrm{O}_{2}$ contents were significantly increased by UV solar exclusion. The soluble protein content was slightly increased by UV solar exclusion. The proline and MDA contents were reduced by UV solar exclusion, and the proline content was significantly reduced by UV solar exclusion.

\section{Secondary metabolite contents}

The secondary metabolite contents were studied in $P$. vulgaris under UV solar exclusion (Table 5). The total phenolic, total flavonoid, caffeic acid, rosmarinic acid and hyperoside contents were significantly increased under UV solar exclusion, but the increase in the total flavonoid content under UV solar exclusion was not significantly different compared to the results obtained with control treatment. The oleanolic acid and ursolic acid contents were significantly increased under UV solar exclusion, and the total polysaccharide content increased but was not significant. Additionally, the salviaflaside content was significantly reduced by UV solar exclusion.

\section{In vitro antioxidant activities}

The in vitro antioxidant activities of ethanol extracts of $P$. vulgaris spicas were studied under UV solar exclusion (Table 6). The scavenging activities of DPPH. and ABTS. ${ }^{+}$were significantly enhanced under UV solar exclusion compared to the results obtained with control samples. According to the scavenging DPPH. radical activity results, ethanol extracts of $P$. vulgaris spicas subjected to UV solar exclusion showed significantly higher free radical scavenging activities than control extracts. These results also indicate that the ethanol extracts of $P$. vulgaris spicas under UV solar exclusion demonstrated higher $\mathrm{ABTS}^{+}$free radical scavenging activities than control samples.

\section{Discussion}

In the present study, the effect of UV solar exclusion on the morphology, physiology, secondary metabolites and antioxidant activities of $P$. vulgaris were investigated. In our study, we observed significant increases in the branch number per plant, stem weight and whole-plant weight of $P$. vulgaris as well as increased spica numbers per plant, spica length, root weight, leaf weight and spica weight (except for a slight decrease in spica width) with UV solar exclusion, which is consistent with observations of other crop and medicinal plants [27]. Previous studies have shown that UV solar exclusion significantly increases PS II efficiency and the photosynthesis rate and induces remarkable increases in the carbonic anhydrase, ribulose-1,5-bisphosphate carboxylase (Rubisco) and nitrate reductase activities; this additional carbon and nitrogen fixation via solar UV exclusion facilitates improvements in both the biomass and economic yield of the plants [28]. Thus, P. vulgaris morphology and biomass productivity were increased by UV solar exclusion.

In this study, the decrease in the total chlorophyll levels with solar UV exclusion was attributable to the decreased synthesis of chlorophyll a and chlorophyll b. However, the extent of the reduction was greater for chlorophyll $b$ 
Table 5 The effects of UV solar exclusion on the total phenolic, total flavonoid, rosmarinic acid, caffeic acid, hyperoside, total polysaccharide, salviaflaside, ursolic acid and oleanolic acid contents in P. vulgaris spicas

\begin{tabular}{lll}
\hline Secondary metabolites & Control & UV solar exclusion \\
\hline Total phenolics (\%) & $1.30 \pm 0.15 \mathrm{~b}$ & $1.97 \pm 0.28 \mathrm{a}$ \\
Total flavonoids (\%) & $4.31 \pm 0.52 \mathrm{a}$ & $4.96 \pm 0.23 \mathrm{a}$ \\
Rosmarinic acid (\%) & $0.28 \pm 0.01 \mathrm{~b}$ & $0.30 \pm 0.00 \mathrm{a}$ \\
Caffeic acid (\%) & $0.02 \pm 0.00 \mathrm{~b}$ & $0.02 \pm 0.00 \mathrm{a}$ \\
Hyperoside (\%) & $0.02 \pm 0.00 \mathrm{~b}$ & $0.04 \pm 0.00 \mathrm{a}$ \\
Total polysaccharides (\%) & $3.68 \pm 0.47 \mathrm{a}$ & $4.09 \pm 0.66 \mathrm{a}$ \\
Salviaflaside (\%) & $0.12 \pm 0.00 \mathrm{a}$ & $0.08 \pm 0.00 \mathrm{~b}$ \\
Ursolic acid (\%) & $0.52 \pm 0.02 \mathrm{~b}$ & $0.62 \pm 0.02 \mathrm{a}$ \\
Oleanolic acid (\%) & $0.10 \pm 0.01 \mathrm{~b}$ & $0.13 \pm 0.01 \mathrm{a}$ \\
\hline
\end{tabular}

Each value is presented as the mean $\pm S D(n=3)$. Different letters in lines indicate a significant difference at $p<0.05$

Table 6 The effects of UV solar exclusion and supplemental UV-B radiation on DPPH. and ABTS.+ radical scavenging activities in ethanol extracts of $P$. vulgaris spicas

\begin{tabular}{|c|c|c|}
\hline Antioxidant activities & Control & UV solar exclusion \\
\hline $\mathrm{DPPH} \cdot(\%)$ & $63.66 \pm 1.95 b$ & $80.82 \pm 0.22 a$ \\
\hline TEAC (mmol L ${ }^{-1}$ trolox) & $0.87 \pm 0.03 b$ & $0.96 \pm 0.01 \mathrm{a}$ \\
\hline
\end{tabular}

Each value is presented as the mean $\pm S D(n=3)$. Different letters in lines indicate a significant difference at $p<0.05$

than for chlorophyll a, causing an increase in the chlorophyll $\mathrm{a} / \mathrm{b}$ ratio following exposure to UV solar exclusion. This result indicated that a higher Chla/Chlb ratio in $P$. vulgaris leaves facilitates adaptation to oxidative stress by maximizing the energy efficiency and allowing plants to maintain efficient and stable operation of photosynthesis under UV solar exclusion.

The present study showed that the carotenoid content was significantly enhanced under solar UV exclusion. Similarly, previous studies showed that the carotenoid levels in medicinal plants were increased under UV solar exclusion [29]. Anthocyanins are well-known antioxidants and ROS scavengers [30] and regulate photo-oxidative damages [31, 32]. The present study revealed that UV solar exclusion stimulated the production of anthocyanin in P. vulgaris leaves, which is consistent with the results of previous studies [33,34]. Thus, the leaf cells of $P$. vulgaris that accumulate carotenoids and anthocyanins are much more effective at eliminating ROS induced by photo-oxidative stress than leaves exposed to control treatments.

In the enzymatic defence system, SOD accelerates the conversion of superoxide to hydrogen peroxide $\left(\mathrm{H}_{2} \mathrm{O}_{2}\right)$, and POD and CAT catalyse $\mathrm{H}_{2} \mathrm{O}_{2}$ breakdown into $\mathrm{H}_{2} \mathrm{O}$ and $\mathrm{O}_{2}$ [35]. APX, an indispensable component of the ascorbate-glutathione cycle required to scavenge $\mathrm{H}_{2} \mathrm{O}_{2}$, is mainly produced in chloroplasts and other cell organelles to maintain the redox state of cells [36]. In addition, GSH is an important antioxidant that protects plant cells against oxidative damage and reacts directly with ROS [37, 38]. The activities of POD, SOD, CAT and APX were increased by UV solar exclusion. Similar results were obtained in a previous study [39]. We hypothesized that UV solar exclusion primarily enhances photo-oxidative damage to $P$. vulgaris plants. By contrast, our results showed that UV solar exclusion caused a slight decrease in the GSH content. These results indicated that UV solar exclusion induced oxidative stress and caused a large amount of $\mathrm{H}_{2} \mathrm{O}_{2}$-induced damage to $P$. vulgaris plant cells, rendering GSH less capable of responding to stress, which is consistent with the results of a previous study [40].

Interestingly, the total soluble protein content in the leaves of $P$. vulgaris increased in UV exclusion samples, which agrees with the results of an earlier study [41]. These results confirmed that UV light exclusion enhanced biomass accumulation and the protein content in leaves due to the increased area and number of leaves resulting from altered photomorphogenesis. The sugar content was enhanced to similar levels following exposure of $P$. vulgaris to UV solar exclusion. The efficient role of sugars as true ROS scavengers during abiotic stress has previously been demonstrated, and the synergistic interaction of sugars and phenolic compounds functions as an integrated redox system in plants to scavenge ROS and enhance stress tolerance [42, 43]. Additionally, these results indicate that soluble protein and soluble sugar are osmotic regulators, and plants adapt to oxidative stress through osmotic regulation by altering the co-accumulation of soluble protein and soluble sugar. Similar results were reported in previous study [44].

Reactive oxygen species accumulation may cause damage to biomolecules, leading to altered metabolic processes in plants. In the present study, the $\mathrm{H}_{2} \mathrm{O}_{2}$ content was significantly increased by UV solar exclusion than by control treatment, which implies photooxidative damage $[45,46]$. Proline accumulation is one of the important non-enzymatic defence systems and this system protects plant cells against ROS generated by photo-oxidative stress in some medicinal plants. UV solar exclusion induce photoinhibition, which stimulates ROS generation as indicated by the presence of MDA-lipid peroxidation products. MDA is widely used as an indicator of physiological stress in plants and causes changes to cell membrane properties, such as enzyme activity, fluidity and ion transport [47]. UV solar exclusion induced photo-oxidative stress 
in $P$. vulgaris, but the increase in MDA production was lower, revealing the high tolerance of these plants to UV solar exclusion. Thus, although large amounts of $\mathrm{H}_{2} \mathrm{O}_{2}$ were induced by photo-oxidative stress, $P$. vulgaris plants did not show any significant physiological damage, suggesting the presence of strong repair mechanisms.

Phenolic compounds are a large category of secondary metabolites in P. vulgaris spicas [2], and the antioxidative activities of phenolic extracts from $P$. vulgaris plants scavenge ROS [48] and suppress lipoperoxidation in pharmacological models [49]. In this study, the total phenolic contents of $P$. vulgaris spicas under UV solar exclusion were significantly higher than those under control treatment. Similar results were previously obtained in other plants $[50,51]$. P. vulgaris under UV exclusion treatment had a significantly higher $\mathrm{H}_{2} \mathrm{O}_{2}$ content than plants grown under the control treatment. ROS may be serve as mediators by initiating the biosynthesis of certain phenolic compounds [52]. These results suggest that increasing the total phenolic content of $P$. vulgaris effectively induces ROS scavenging and decreases the degree of membrane lipid peroxidation under UV solar exclusion.

Flavonoids are important secondary metabolites in $P$. vulgaris spicas [2], demonstrating significant antioxidant activities in in vivo experiments [53]. In the present study, the flavonoid contents in $P$. vulgaris spicas significantly increased under UV solar exclusion, suggesting that increased flavonoids in $P$. vulgaris protect the plants against $\mathrm{H}_{2} \mathrm{O}_{2}$ induced by UV solar exclusion. Similar findings were reported by previous studies [54-56].

Rosmarinic acid is a major phenolic component in $P$. vulgaris spicas [10], and the Chinese Pharmacopoeia considers the amount of rosmarinic acid to be a quality control marker for Spica Prunellae [3]. In our study, the rosmarinic acid content was significantly enhanced by UV solar exclusion in this study. Previous studies indicated that rosmarinic acid possesses excellent ROSscavenging capability and is proposed to be a true photoprotective agent [57]. This photo-oxidative stress leads to the production of $\mathrm{H}_{2} \mathrm{O}_{2}$, which in turn activates and increases the levels of PAL (Phenylalanine-ammonialyase, a key enzyme in the biosynthesis of rosmarinic acid) [58], providing sufficient amounts of substrate to sustain higher levels of rosmarinic acid synthesis in metabolic pathways [59]. This result indicated that increased rosmarinic acid exerted a protective effect on $P$. vulgaris plants against ROS production induced by UV solar exclusion.

Caffeic acid is an important phenolic component in $P$. vulgaris spicas [15]. The $60 \%$ ethanol extract of $P$. vulgaris contains the major bioactive compounds containing caffeic acid and shows high antioxidant activity in in vitro and in vivo experiments [60]. High amounts of caffeic acid in $P$. vulgaris spica extracts indicate that the antioxidative activities of caffeic acid may be responsible for antinociceptive and antidiabetogenic effects in diabetic mice models [61]. In this study, the caffeic acid content in $P$. vulgaris spicas significantly increased under UV solar exclusion, which is consistent with previous reports [62]. These results suggest that the increased caffeic acid content observed in $P$. vulgaris spicas under photo-oxidative stress may prevent lipid peroxidation and scavenge ROS in $P$. vulgaris cells.

Hyperoside, the main flavonol glycoside component in P. vulgaris spicas [4], was found to inhibit $\mathrm{H}_{2} \mathrm{O}_{2}$-induced apoptosis in Chinese hamster lung fibroblast cells and increase the CAT and glutathione peroxidase (GSH-Px) activities [63]. In this study, the UV solar exclusion significantly promoted hyperoside accumulation in $P$. vulgaris spicas, which is consistent with the results of a previous study [64]. Previous studies also indicated that hyperoside was an effective ROS scavenger and demonstrated the highest DPPH. scavenging capability [65]. Therefore, increased hyperoside levels in $P$. vulgaris spicas may act as compensators to scavenge ROS generated from UV solar exclusion.

Polysaccharides are an important type of secondary metabolite in P. vulgaris spicas [2]. Recently, a study suggested that $P$. vulgaris polysaccharides could be explored as potential antioxidant and immunomodulatory agents for complementary medicine and may be candidates for the treatment of hypoimmunity and immunodeficiency diseases [18]. In this study, UV solar exclusion was beneficial for the accumulation of polysaccharides in $P$. vulgaris, especially when the plants were under the oxidative stress, which was similar to the results obtained in previous studies [66]. Polysaccharides effectively eliminate ROS induced by photo-oxidative stress, protecting DNA strand breaks and inhibiting membrane lipid peroxidation.

Salviaflaside is a major phenolic glycoside component in $P$. vulgaris spicas and possibly acts as a quality indicator for Spica Prunellae [11]. In our study, the salviaflaside content was significantly decreased by UV solar exclusion. A similar result was obtained in a previous study [21]. We speculate that $\beta$-glucosidase activities are likely involved in the metabolism of phenolic glycosides. Additionally, salviaflaside reduced the performance of $P$. vulgaris spicas, potentially because $\beta$-glucosidase activity is inhibited or depressed by photo-oxidative stress; similar results have been found in previous studies [67-69]. This result suggested that the decrease in salviaflaside upon photo-oxidative stress, which induced large amounts of 
$\mathrm{H}_{2} \mathrm{O}_{2}$, resulted in combined effects on enzymatic photodegradation and reduced enzyme production due to the decreased metabolism of the organism or decreased enzyme synthesis. This may explain the decreased salviaflaside content observed in $P$. vulgaris spicas under UV solar exclusion.

Ursolic acid and oleanolic acid are most prevalent in $P$. vulgaris spicas [4] and exhibit many bioactivities, including hepatoprotection, anti-inflammatory, antitumour, anti-hyperglycemia and antifungal effects [16, 17]. In this study, the ursolic acid and oleanolic acid contents were significantly increased under UV solar exclusion. Previous studies have shown that ursolic acid and oleanolic acid, which have similar chemical structures, demonstrate scavenging activity against ROS and inhibit peroxidation in rat liver homogenates [70,71]. Terpenoids have been shown to possess antioxidant properties in different situations, particularly against lipid peroxidation, due to their high lipophilicity [72]. Based on this information, the enhanced ursolic acid and oleanolic acid contents of $P$. vulgaris spicas may contribute to ROS scavenging and stabilise the membrane capacity during oxidative stress under UV solar exclusion.

The antioxidant activities of ethanol extracts of $P$. vulgaris spicas were investigated by detecting ABTS. ${ }^{+}$and scavenging DPPH. radicals. The results suggested that all ethanol extracts from $P$. vulgaris spicas under different treatments possessed antioxidative properties. All ethanol extracts from $P$. vulgaris spicas under UV solar exclusion were more efficient at scavenging DPPH. free radicals than ethanol extracts from spicas under control treatment. This result provides evidence that ethanol extracts of $P$. vulgaris spicas subjected to photo-oxidative stress contain more antioxidants and increased the bioactive compound contents. Previous studies have shown that phenolic compounds are the major contributors to antioxidative activities [73]. The antioxidative activities of phenolic acid depends to a large extent on the compound structure, especially the number and distribution of hydroxyl groups $(-\mathrm{OH})$ [74]. A compound has much higher antioxidative activity when there are two $-\mathrm{OH}$ groups in the ortho position (e.g., caffeic acid) [75]. Similar results were presented in earlier works [76].

\section{Conclusions}

Prunella vulgaris possesses strong repair mechanisms and adapts to UV solar exclusion. Increased levels of enzymes, non-enzymatic antioxidant systems and osmolytes play crucial roles in protecting $P$. vulgaris against UV solar exclusion. There were significant increases in the phenolic and flavonoid compound contents and in the in vitro antioxidative properties of $P$. vulgaris spicas under UV solar exclusion. Our study demonstrated that $P$. vulgaris activates several antioxidant defence systems against oxidative damage caused by photo-oxidative stress.

\section{Methods}

\section{Plant materials and growth conditions}

This experiment was conducted on the experimental farm of the College of Pharmaceutical Sciences, Chengdu Medical College, Chengdu, located in the provincial capital of Sichuan, PR China (longitude: $104^{\circ} 19^{\prime} \mathrm{E}$, latitude: $30^{\circ} 82^{\prime} \mathrm{N}$, altitude: $449 \mathrm{~m}$ ).

Seeds of $P$. vulgaris were sterilized with $9 \% \mathrm{H}_{2} \mathrm{O}_{2}$ for $30 \mathrm{~min}$ followed by several rinses with distilled water, after which the seeds were planted in the experimental field of Chengdu Medical College on 25 November 2016 and subjected to regular water and fertilizer management and weeding. Then, $P$. vulgaris uniform seedlings (six-leaf stage) were transplanted into plastic pots (17-cm diameter and 12-cm height) with $850 \mathrm{~g}$ of nutrient soil (pH: 7.05, soil organic matter: $24.57 \mathrm{~g} \mathrm{~kg}^{-1}$, available-N: $85.89 \mathrm{~g} \mathrm{~kg}^{-1}$, available-P: $15.28 \mathrm{~g} \mathrm{~kg}^{-1}$, available- $\mathrm{K}_{2} \mathrm{O}$ : $150.27 \mathrm{~g} \mathrm{~kg}^{-1}$ ) and 3 seedlings per pot on 17 March 2017 . Potted plants were placed in the experimental greenhouse with $60-70 \%$ relative humidity, $792 \mu \mathrm{mol} \mathrm{m}^{-2} \mathrm{~s}^{-1}$ of photosynthetically active radiation (PAR), and $22{ }^{\circ} \mathrm{C} / 14{ }^{\circ} \mathrm{C}$ (day/night) air temperatures. The plants were inspected daily and watered as required.

On 12 May 2017, the P. vulgaris plants were randomly divided into two groups: the control group (CK) and UV solar exclusion group. Under ambient conditions, the light intensities of PAR and UV-B radiation were $25,000 \pm 100 \mathrm{l} \times$ and $700 \pm 20 \mu \mathrm{W} \mathrm{cm} \mathrm{cm}^{-1}$, respectively. The light intensity and UV-B radiation were measured on clear days at 10:30 and 11:00 using a TES-1335 Digital Luxmeter (Rotronic, Taipei, Taiwan) and a portable light meter (UV-340A, Lutron, Taiwan) positioned at the top of the plant canopy, respectively. UV radiation was excluded by the application of an anti-UV polyethylene film $(150 \mu \mathrm{m})$ (Shanghai Zhuiguang Technology Co., LTD, Shanghai, China) during full-flowering stage for 13 days; this treatment allowed the transmittance of more than $92 \%$ of natural light, the exclusion of more than $80 \%$ of UV-B radiation and the exclusion of more than $99 \%$ of UV-A radiation. Under solar UV exclusion condition, the light intensity of UV-B radiation was $100 \pm 10 \mu \mathrm{W} \mathrm{cm} \mathrm{cm}^{-2} \mathrm{~nm}^{-1}$. The experiment treatments were completed on 24 May 2017.

Fresh leaves of $P$. vulgaris were collected on 24 May 2017 and then immediately frozen in liquid nitrogen and stored at $-80{ }^{\circ} \mathrm{C}$ to assess physiological and biochemical indicators. Whole plants were harvested on 5 June 2017 and dried at $70{ }^{\circ} \mathrm{C}$ for $12 \mathrm{~h}$ for biomass measurements. Spicas were powdered and passed through a 60-mesh 
sieve to determine the active ingredient contents and in vitro antioxidant capacities of ethanol extracts of $P$. vulgaris.

\section{Plant growth parameters}

Plant growth parameters, specifically the number of branches, number of spicas, spica length and width, weight of different organs (roots, stem, leaves and spica) and whole plant weight, were measured. The spica length and width were determined with a Vernier calliper, and the weight was measured using an electronic balance (JJ124BC, Electronic Balance Test Instrument Factory, Changshu, China).

\section{Photosynthetic pigments and anthocyanin contents}

Chlorophyll and carotenoids were extracted from $0.2 \mathrm{~g}$ of fresh leaf cuttings with $15 \mathrm{~mL}$ of $95 \%$ ethanol and then sealed and soaked in the dark at room temperature for $48 \mathrm{~h}$, shaking $3-4$ times; the final extract was obtained by adding $95 \%$ ethanol to a volume of $20 \mathrm{~mL}$. The absorbances at 470, 649 and $665 \mathrm{~nm}$, which are the wavelengths of the maximum absorbances of chlorophyll a, chlorophyll $b$ and carotenoids in ethanol, respectively, were measured with a 752 UV-visible spectrophotometer (Shanghai Jinghua Technological Instrument, Shanghai, China). Each treatment was repeated three times. The chlorophyll a, chlorophyll b and carotenoid contents were calculated using equations and extinction coefficients according to the previous methods [23].

Anthocyanins were extracted from $0.5 \mathrm{~g}$ of fresh leaf cuttings with $5 \mathrm{~mL}$ of acidified methanol (methanol: $\mathrm{HCl}=99: 1, \mathrm{~V}: \mathrm{V})$ in the dark at room temperature for $72 \mathrm{~h}$, with shaking 3-4 times. The anthocyanin content was estimated by recording the absorbances at 530 and $280 \mathrm{~nm}$, respectively, using a $752 \mathrm{UV}$-visible spectrophotometer (Shanghai Jinghua Technological Instrument, Shanghai, China). The results were expressed as $\mathrm{A} \mathrm{g}^{-1}$ FW. Each treatment was repeated three times.

\section{Peroxidase activity}

Briefly, $0.5 \mathrm{~g}$ of fresh leaves were placed in $4.5 \mathrm{~mL}$ of a solution containing $0.1 \mathrm{~mol} \mathrm{~L}^{-1}$ phosphate buffer $(\mathrm{pH}$ 7.33), ground to powder in liquid nitrogen, and swirled at low temperature for full extraction. The homogenate was centrifuged at $3500 \mathrm{rpm}$ for $10 \mathrm{~min}$ at $4{ }^{\circ} \mathrm{C}$, and the supernatant was collected to determine the activity of POD using commercial assay kits (Nanjing Jiancheng Bioengineering Institute, Nanjing, China). Enzyme activity was determined by measuring the change in absorbance at $420 \mathrm{~nm}$ in units of $\mathrm{Umg}$ prot $^{-1}$, defined as the amount of enzyme per microgram of tissue protein that decomposes $1 \mu \mathrm{g}$ of enzyme catalytic substrate at $37^{\circ} \mathrm{C}$.

\section{Catalase and superoxide dismutase activities}

Briefly, $1.0 \mathrm{~g}$ of fresh leaves were added to $4.0 \mathrm{~mL}$ of a solution containing $0.1 \mathrm{~mol} \mathrm{~L}^{-1}$ phosphate buffer $(\mathrm{pH}$ 7.33), ground to a powder in liquid nitrogen, and swirled at low temperature for full extraction. The homogenate was centrifuged at $3500 \mathrm{rpm}$ for $10 \mathrm{~min}$ at $4{ }^{\circ} \mathrm{C}$, and the supernatant was collected to determine the activities of CAT and SOD using commercial assay kits (Nanjing Jiancheng Bioengineering Institute, Nanjing, China). CAT activity was measured at $405 \mathrm{~nm}$ in $\mathrm{Umg}$ prot $^{-1}$, defined as one unit of energy per milligram of tissue protein that decomposes $1 \mu \mathrm{mol}$ of hydrogen peroxide $\left(\mathrm{H}_{2} \mathrm{O}_{2}\right)$ per second. SOD activity was determined by measuring the change in absorbance at $550 \mathrm{~nm}$ in Umg $\operatorname{prot}^{-1}$, defined as the amount of SOD per unit of SOD activity when SOD inhibition was $50 \%$ in $1 \mathrm{~mL}$ of reaction solution per milligram of tissue protein.

\section{Ascorbate peroxidase activity}

Briefly, $0.5 \mathrm{~g}$ of fresh leaves was added to $4.5 \mathrm{~mL}$ of a solution containing $0.1 \mathrm{~mol} \mathrm{~L}^{-1}$ phosphate buffer $(\mathrm{pH}$ 7.33), ground to a powder in liquid nitrogen, and swirled at low temperature for full extraction. The homogenate was centrifuged at $10,000 \mathrm{rpm}$ for $10 \mathrm{~min}$ at $4{ }^{\circ} \mathrm{C}$, and the supernatant was collected to determine the activity of APX using commercial assay kits (Nanjing Jiancheng Bioengineering Institute, Nanjing, China). APX activity was measured at $290 \mathrm{~nm}$ in units of $\mathrm{Umg}_{\mathrm{mot}}{ }^{-1}$, defined as $1 \mu \mathrm{mol}$ of ascorbic acid (AsA) per milligram of tissue protein per $\mathrm{mL}$ of reaction.

\section{Glutathione content}

Briefly, $0.5 \mathrm{~g}$ of fresh leaves were added to $4.5 \mathrm{~mL}$ of a solution containing $0.1 \mathrm{~mol} \mathrm{~L}^{-1}$ phosphate buffer $(\mathrm{pH}$ 7.33), ground to a powder in liquid nitrogen, and swirled at low temperature for full extraction. The homogenate was centrifuged at $2500 \mathrm{rpm}$ for $10 \mathrm{~min}$ at $4{ }^{\circ} \mathrm{C}$, and the supernatant was collected to determine the content of GSH using commercial assay kits (Nanjing Jiancheng Bioengineering Institute, Nanjing, China). Absorbance was measured at $420 \mathrm{~nm}$ in milligrams of glutathione per gram of protein.

\section{Soluble protein, proline and malondialdehyde contents} Briefly, $0.5 \mathrm{~g}$ of fresh leaves were added to $4.5 \mathrm{~mL}$ of a solution containing $0.1 \mathrm{~mol} \mathrm{~L}^{-1}$ phosphate buffer $(\mathrm{pH}$ 7.33), ground to a powder in liquid nitrogen, and swirled at low temperature for full extraction. The homogenate was centrifuged at $3500 \mathrm{rpm}$ for $10 \mathrm{~min}$ at $4{ }^{\circ} \mathrm{C}$, and the supernatant was collected to determine the soluble protein, proline and MDA contents using commercial assay kits (Nanjing Jiancheng Bioengineering Institute, Nanjing, China). The soluble protein content was measured 
at $595 \mathrm{~nm}$ in g proteins $\mathrm{l}^{-1} \mathrm{FW}$. The proline content was measured at $520 \mathrm{~nm}$ in micrograms per gram of tissue wet weight. The MDA content was measured at $532 \mathrm{~nm}$ in $\mathrm{nmol} \mathrm{mg}^{-1}$ proteins.

\section{Soluble sugar content}

Briefly, $0.2 \mathrm{~g}$ of fresh leaves were added to $2 \mathrm{~mL}$ of distilled water, fully ground into a homogenate, and placed into a boiling water bath for $10 \mathrm{~min}$, then cooled and centrifuged at $4000 \mathrm{rpm}$ for $10 \mathrm{~min}$ at room temperature. The supernatant was diluted 10 times with distilled water and shaken well according to the method provided by the kit to determine the soluble sugar content (Nanjing Jiancheng Bioengineering Institute, Nanjing, China). The soluble sugar content was measured at $620 \mathrm{~nm}$ in $\mathrm{mg} \mathrm{mg} \mathrm{m}^{-1}$ proteins.

\section{Hydrogen peroxide content}

Briefly, $0.5 \mathrm{~g}$ of fresh leaves were added to $4.5 \mathrm{~mL}$ of a solution containing $0.1 \mathrm{~mol} \mathrm{~L}^{-1}$ phosphate buffer $(\mathrm{pH}$ 7.33), ground to a powder in liquid nitrogen, and swirled at low temperature for full extraction. The homogenate was centrifuged at $10,000 \mathrm{rpm}$ for $10 \mathrm{~min}$ at $4{ }^{\circ} \mathrm{C}$, and the supernatant was collected to determine the $\mathrm{H}_{2} \mathrm{O}_{2}$ content using commercial assay kits (Nanjing Jiancheng Bioengineering Institute, Nanjing, China). The $\mathrm{H}_{2} \mathrm{O}_{2}$ content was measured at $405 \mathrm{~nm}$ in millimoles per milligram of protein.

\section{Total phenolic content}

One gram of dried spica powder, weighed precisely, was combined with $10 \mathrm{~mL}$ of $80 \%$ ethanol, and reflux extraction was performed for $1.5 \mathrm{~h}$ at $90^{\circ} \mathrm{C}$ and repeated three times. Reaction conditions were optimized at ambient temperature. One millilitre of the above-mentioned extract solution was mixed with $0.5 \mathrm{~mL}$ of Folin-Ciocalteu reagent and $1.7 \mathrm{~mL}$ of $20 \% \mathrm{Na}_{2} \mathrm{CO}_{3}$ in a test tube for $60 \mathrm{~min}$. The absorbance was measured at $760 \mathrm{~nm}$ using a 752 UV-visible spectrophotometer (Shanghai Jinghua Technological Instrument, Shanghai, China). Gallic acid was used to generate a standard calibration curve, and the results were expressed as milligrams of gallic acid equivalents per $100 \mathrm{mg}$ of spica dry weight (\%).

\section{Total flavonoid content}

One gram of dried spica powder was extracted three times with $10 \mathrm{~mL}$ of $35 \%$ ethanol solution in a water bath for $3.5 \mathrm{~h}$ at $86{ }^{\circ} \mathrm{C}$. The total flavonoid content in $P$. vulgaris was determined by a spectrophotometric method using a 752 UV-visible spectrophotometer (Shanghai Jinghua Technological Instrument, Shanghai, China) measuring the absorbance at $510 \mathrm{~nm}$, using rutin as the standard. Reaction conditions were optimized at ambient temperature and in the dark. One millilitre of the abovementioned extract solution was combined with $0.7 \mathrm{~mL}$ of $50 \mathrm{mg} \mathrm{mL}{ }^{-1} \mathrm{NaNO}_{3}$ and reacted for $7 \mathrm{~min}$. Next, $0.3 \mathrm{~mL}$ of $100 \mathrm{mg} \mathrm{mL}^{-1} \mathrm{AlCl}_{3}$ was mixed with the solution for $6 \mathrm{~min}$, and $5.0 \mathrm{~mL}$ of $1 \mathrm{~mol} \mathrm{~L}^{-1} \mathrm{NaOH}$ solution was added. The results were expressed as milligrams of rutin equivalents per $100 \mathrm{mg}$ of spica dry weight (\%).

\section{Total polysaccharide content}

Prunella vulgaris dried spica power $(0.2 \mathrm{~g})$ was refluxed three times with $100 \mathrm{~mL}$ of $95 \%$ ethanol for $3 \mathrm{~h}$ at $95^{\circ} \mathrm{C}$, and the residue was thoroughly washed with $95 \%$ ethanol to remove ethanol-soluble constituents. Then, the residue was refluxed with an appropriate amount of petroleum ether at $80{ }^{\circ} \mathrm{C}$ for $0.5 \mathrm{~h}$ to de-colour and achieve petroleum ether recovery. Next, the residue was sequentially extracted in a hot water bath with $50 \mathrm{~mL}, 20 \mathrm{~mL}$, and $20 \mathrm{~mL}$ of distilled water for $0.5 \mathrm{~h}$ at $40{ }^{\circ} \mathrm{C}$. The polysaccharide content was determined using a 752 UV-visible spectrophotometer (Shanghai Jinghua Technological Instrument, Shanghai, China) measuring the absorbance at $490 \mathrm{~nm}$ with glucose as the standard. One millilitre of the above-mentioned extract solution was mixed with $1 \mathrm{~mL}$ of distilled water and $1 \mathrm{~mL}$ of $6 \%$ phenol solution; then, $5 \mathrm{~mL}$ of concentrated sulfuric acid was rapidly added, shaken and reacted at ambient temperature for $5 \mathrm{~min}$, in a boiling water bath for $15 \mathrm{~min}$, and then cooled to room temperature to determine the content. The results were expressed as milligrams of rutin equivalents per $100 \mathrm{mg}$ of spica dry weight (\%).

\section{Rosmarinic acid, salviaflaside, caffeic acid and hyperoside contents}

Two grams of dried spica powder was mixed with $15 \mathrm{~mL}$ of $80 \%$ methanol in an ultrasonic bath for $35 \mathrm{~min}$ at ambient temperature, and then the extracted solution was centrifuged at 12,000 $\mathrm{rpm}$ for $15 \mathrm{~min}$. The supernatant was passed through a $0.45-\mu \mathrm{m}$ organic membrane filter prior to HPLC analysis. A Dionex UltiMate 3000 HPLC System (Dionex Corp., Sunnyvale, CA, USA) equipped with a diode array detector (DAD-3000) and a Uranus C18 column $(250 \mathrm{~mm} \times 4.6 \mathrm{~mm})$ was used to quantify the extracts $(10 \mu \mathrm{L})$. The mobile phase consisted of chromatographic methanol (solvent A) and $0.2 \% \mathrm{NaH}_{2} \mathrm{PO}_{4}$ solution (solvent $\mathrm{B}$ ), the flow rate was $0.8 \mathrm{~mL} \mathrm{~min}^{-1}$, and the following multilinear gradient was applied: $20-40 \%$ A (0-20 min), $40-70 \%$ A (20-35 min), 70-90\% A (35$45 \mathrm{~min})$, and $90-20 \% \mathrm{~A}(45-60 \mathrm{~min})$. The column oven temperature was set to $30^{\circ} \mathrm{C}$ with a run time of $60 \mathrm{~min}$. UV wavelengths were monitored at $325 \mathrm{~nm}$ for caffeic acid salviaflaside and rosmarinic acid and $360 \mathrm{~nm}$ for hyperoside. The identification of each peak was based on the retention time and the chromatography of the 
authentic standards. Concentrations of phenolic acids and flavonoid compounds were calculated according to the calibration curves of the standards, and the results were presented as milligrams per $100 \mathrm{mg}$ of spica dry weight (\%).

\section{Ursolic acid and oleanolic acid contents}

One gram of dried spica powder was combined with an appropriate amount of ether, soaked overnight, and refluxed for $3 \mathrm{~h}$ at $45{ }^{\circ} \mathrm{C}$ until the residue was colourless. The residue was then soaked with petroleum ether two times, the residual solvent was evaporated, and the extracts were dissolved with methanol. The extracted solution was passed through a $0.45-\mu \mathrm{m}$ organic membrane filter prior to HPLC analysis. A Dionex UltiMate 3000 HPLC System (Dionex Corp., Sunnyvale, CA, USA) equipped with a diode array detector (DAD$3000)$ and a Uranus C18 column $(250 \mathrm{~mm} \times 4.6 \mathrm{~mm})$ was used to quantify the extracts $(10 \mu \mathrm{L})$. The mobile phase consisted of chromatographic methanol (90\%) and $5 \% \mathrm{CH}_{3} \mathrm{COONH}_{4}$ solution (10\%), the flow rate was $0.6 \mathrm{~mL} \mathrm{~min}{ }^{-1}$, the column oven temperature was $25^{\circ} \mathrm{C}$, and the detection wavelength was $210 \mathrm{~nm}$, with a run time of $35 \mathrm{~min}$. The ursolic acid and oleanolic acid contents were calculated according to the calibration curves of the standards, and the results were presented as milligrams per $100 \mathrm{mg}$ of spica dry weight (\%).

\section{DPPH . free radical scavenging assay}

One gram of dried spica powder was extracted by ultrasound with $30 \mathrm{~mL}$ of $70 \%$ ethanol solution for $30 \mathrm{~min}$ at $70{ }^{\circ} \mathrm{C}$. One millilitre of the above-mentioned extract solution was mixed with $4.0 \mathrm{~mL}$ of $0.004 \% \mathrm{DPPH}$. solution and maintained at room temperature in the dark for $30 \mathrm{~min}$. The absorbance was measured at $517 \mathrm{~nm}$ using a 752 UV-visible spectrophotometer (Shanghai Jinghua Technological Instrument, Shanghai, China) against a methanol blank. The results were expressed as the percentage of DPPH. radical inhibition (\%). All tests and analyses were run three times and averaged. Calculations were based on the following equation:

$$
\begin{aligned}
& \mathrm{DPPH} \cdot \text { scavenging effect }(\%) \\
& \quad=[\mathrm{A} 0-(\mathrm{A} 1-\mathrm{A} 2 / \mathrm{A} 0)] \times 100 \%
\end{aligned}
$$

where $\mathrm{A} 0$ is the absorbance of the DPPH. solution without sample ( $4 \mathrm{~mL}$ of DPPH $+1 \mathrm{~mL}$ of methanol), A1 is the absorbance of the test sample mixed with DPPH. solution ( $4 \mathrm{~mL}$ of DPPH $+1 \mathrm{~mL}$ of sample) and $\mathrm{A} 2$ is the absorbance of the sample without DPPH. solution $(4 \mathrm{~mL}$ of methanol $+1 \mathrm{~mL}$ of sample).

\section{Trolox equivalent antioxidant capacity (TEAC assay)}

One gram of dried spica powder was extracted by ultrasound with $30 \mathrm{~mL}$ of $70 \%$ ethanol solution for $30 \mathrm{~min}$ at $70{ }^{\circ} \mathrm{C}$. A $0.1-\mathrm{mL}$ aliquot of the above-mentioned extract solution was mixed with $3.9 \mathrm{~mL}$ of working fluid $(7 \mathrm{mmol}$ $\mathrm{L}^{-1}$ ABTS $^{+}$) and with $2.45 \mathrm{mmol} \mathrm{L}^{-1} \mathrm{~K}_{2} \mathrm{~S}_{2} \mathrm{O}_{8}$, incubated in the dark at $23{ }^{\circ} \mathrm{C}$ for $12-16 \mathrm{~h}$, then diluted in buffer (pH 7.4) until its absorbance was $0.700 \pm 0.005$ at $734 \mathrm{~nm}$. The solution was then incubated at $23{ }^{\circ} \mathrm{C}$ for $6 \mathrm{~min}$, and the absorbance was read at $734 \mathrm{~nm}$ using a $752 \mathrm{UV}$-visible spectrophotometer (Shanghai Jinghua Technological Instrument, Shanghai, China). The percent inhibition was calculated against a blank control. All tests and analyses were run three times and averaged. Calculations were based on the following equation:

$$
\text { ABTS } .{ }^{+} \text {scavenging effect }(\%)=[(1-\mathrm{A} 1) / \mathrm{A} 2] \times 100 \%
$$

where $\mathrm{A} 1$ is the absorbance of the test sample mixed with working solution $(3.9 \mathrm{~mL}$ of working solution $+0.1 \mathrm{~mL}$ of sample) and A2 is the absorbance of working solution without sample $(3.9 \mathrm{~mL}$ of working solution $+0.1 \mathrm{~mL}$ of water).

Trolox was used to generate a standard calibration curve, and the results were expressed as TEAC. The concentration of antioxidants giving the same percent inhibition of ABTS. ${ }^{+}$as that of $1 \mathrm{mM}$ Trolox was considered TEAC.

\section{Statistical analyses}

Data are presented as the mean \pm SD. Significant differences were determined by one-way analysis of variance (ANOVA) followed by Duncan's multiple range test using SPSS 17.0 software (SPSS, Chicago, IL, USA).

\section{Abbreviations}

APX: ascorbate peroxidase; AsA: ascorbic acid; CAT: catalase; DAD: diode array detector; DPPH: 1, 1-diphenyl-2-picrylhydrazyl; GSH: glutathione; $\mathrm{H}_{2} \mathrm{O}_{2}$ : hydrogen peroxide; MDA: malondialdehyde; POD: peroxidase; ROS: reactive oxygen species; SOD: superoxide dismutase; TEAC: trolox equivalent antioxidant capacity; UV: ultraviolet.

\section{Authors' contributions}

YHC conceived the research and designed the study. XRZ performed the experiments and wrote the paper. QSG and WMW contributed to the revisions of the manuscript. LPC and CL performed some of the experiments. MZ and QQ participated in analyzing data. All authors contributed to the revision of this manuscript. All authors read and approved the final manuscript.

\footnotetext{
Author details

${ }^{1}$ College of Pharmaceutical Sciences, Chengdu Medical College,

Chengdu 610500, Sichuan, China. ${ }^{2}$ Institute of Chinese Medicinal Materials, Nanjing Agricultural University, Nanjing 210095, Jiangsu, China. ${ }^{3}$ Rice Research Institute, Sichuan Agricultural University, Chengdu 611130, Sichuan, China. ${ }^{4}$ Shanghai Traditional Chinese Medicine Co., LTD., Shanghai 200002, China.
} 


\section{Acknowledgements}

We thank Prof. Qiaosheng Guo and Prof. Wenming Wang for advice and comments on this manuscript.

\section{Competing interests}

The authors declare that they have no competing interests.

\section{Availability of data and materials}

All data generated or analyzed during this study are included in this published article and its supplementary information files or available from the corresponding author on reasonable request.

\section{Consent for publication}

All the authors listed have approved the manuscript that is enclosed.

\section{Ethics approval and consent to participate}

Not applicable.

\section{Funding}

This study was funded by programs of the National Nature Science Foundation of China (31500263, 30772730 and 81072986), the China Postdoctoral Science Foundation (2014M560726 and 2016T90869), Basic Research Program of Sichuan Province of China (2019YJ0368) and the Sichuan Province Undergraduates Innovating Experimentation Project (201813705027).

\section{Publisher's Note}

Springer Nature remains neutral with regard to jurisdictional claims in published maps and institutional affiliations.

Received: 24 October 2018 Accepted: 26 March 2019

Published online: 01 April 2019

\section{References}

1. Chen YH, Guo QS, Liu L, Liao L, Zhu ZB. Influence of fertilization and drought stress on the growth and production of secondary metabolites in Prunella vulgaris L. J Med Plants Res. 2011;5(9):1749-55.

2. Chen YH, Yu MM, Zhu ZB, Zhang LX, Guo QS. Optimisation of potassium chloride nutrition for proper growth, physiological development and bioactive component production in Prunella vulgaris L. PLOS ONE. 2013:8:e66259.

3. Board of Pharmacopoeia of P.R. China. Pharmacopoeia of the People's Republic of China. Beijing: China Medico-Pharmaceutical Science \& Technology Puhlishig House; 2015.

4. Bai YB, Xia BH, Xie WJ, Zhou YM, Xie JC, Li HQ, et al. Phytochemistry and pharmacological activities of the genus Prunella. Food Chem. 2016;204(1):483-96.

5. Liao L, Guo QS, Wang ZY, Liu L, Zhu ZB. Genetic diversity analysis of Prunella vulgaris in China using ISSR and SRAP markers. Biochem Syst Ecol. 2012;45:209-17.

6. Chen YH, Guo QS, Zhu ZB, Zhang LX. Changes in bioactive components related to the harvest time from the spicas of Prunella vulgaris. Pharm Biol. 2012;50:1118-22.

7. Chen YH, Zhu ZB, Guo QS, Zhang LX, Zhang XM. Variation in concentrations of major bioactive compounds in Prunella vulgaris L. related to plant parts and phenological stages. Biol Res. 2012;45(2):171-5

8. Chen YH, Guo QS, Zhu ZB, Zhang LX, Dai XL. Comparative analysis of the essential oil of flowers, leaves and stems of Prunella vulgaris L. J Essent Oil Bear PI. 2012;15:662-6.

9. Cheung HY, Zhang QF. Enhanced analysis of triterpenes, flavonoids and phenolic compounds in Prunella vulgaris L. by capillary zone electrophoresis with the addition of running buffer modifiers. J Chromatogr A. 2008;1213(2):231-8

10. Psotova J, Kolar M, Sousek J, Svagera Z, Vicar J, Ulrichova J. Biological activities of Prunella vulgaris extract. Phytother Res. 2003;17(9):1082-7.

11. Feng WH, Li C, Xin WM, Lin LM, Xia BH, Rong LX, et al. Exploration on feasibility of introducing bioassay method into quality evaluation of Chinese herbal medicines by studying on the correlation between antioxidant activity of Prunella vulgaris and its total phenolic acids content for example. China J Chin Mater Med. 2016;41(14):2660-8.

12. Liu RL, Xiong QJ, Shu Q, Wu WN, Cheng J, Fu H, et al. Hyperoside protects cortical neurons from oxygen-glucose deprivation-reperfusion induced injury via nitric oxide signal pathway. Brain Res. 2012;1469:164-73.

13. Kim HI, Quan FS, Kim JE, Lee NR, Kim HJ, Jo SJ, et al. Inhibition of estrogen signaling through depletion of estrogen receptor alpha by ursolic acid and betulinic acid from Prunella vulgaris var. lilacina. Biochem Biophys Res Commun. 2014;451(2):282-7.

14. Paolessi P, Nicoletti M, Catoni R, Puglielli G, Toniolo C, Gratani L. Cistus creticus subsp. eriocephalus as a model for studying plant physiological and metabolic responses to environmental stress factors. Chem Biodivers. 2015;12(12):1862-70

15. Zhang XR, Chen YH, Guo QS, Wang WM, Liu L, Fan J, et al. Short-term UV-B radiation effects on morphology, physiological traits and accumulation of bioactive compounds in Prunella vulgaris L. J Plant Interact. 2017;12(1):348-54

16. Ryu SY, Oak MH, Yoon SK, Cho DI, Yoo GS, Ki TS, et al. Anti-allergic and anti-inflammatory triterpenes from the herb of Prunella vulgaris. Planta Med. 2000;66(4):358-60

17. Wu PK, Tai WCS, Liang ZT, Zhao ZZ, Hsiao WLW. Oleanolic acid isolated from Oldenlandia diffusa exhibits a unique growth inhibitory effect against ras-transformed fibroblasts. Life Sci. 2009;85(3-4):113-21.

18. Li C, Huang Q, Fu X, Yue XJ, Liu RH, You LJ. Characterization, antioxidant and immunomodulatory activities of polysaccharides from Prunella vulgaris Linn. Int J Biol Macromol. 2015;75:298-305.

19. Rousseaux CM, Flint SD, Searles PS, Caldwell MM. Plant responses to current solar ultraviolet- B radiation and supplemented solar ultraviolet$B$ radiation simulating ozone depletion: an experimental comparison. Photochem Photobiol. 2004:80(2):224-30.

20. Kataria S, Guruprasad KN. Exclusion of solar UV radiation improves photosynthetic performance and yield of wheat varieties. Plant Physiol Biochem. 2015;97:400-11.

21. Ferreira MI, Uliana MR, Costa SM, Magro M, Vianello F, Ming LC, et al. Exclusion of solar UV radiation increases the yield of curcuminoid in Curcuma longa L. Ind Crop Prod. 2016;89:188-94.

22. Wu Z, Guo QS, Wang QY, Zhou LJ, Zhang ZY, Zhang LX, et al. Effects of lead, copper and cadmium stresses on growth and inherent quality of Prunalla vulgaris. China J Chin Materia Med. 2010;35(3):263-7.

23. Chen YH, Liu L, Guo QS, Zhu ZB, Zhang LX. Effects of different water management options and fertilizer supply on photosynthesis, fluorescence parameters and water use efficiency of Prunella vulgaris seedlings. Biol Res. 2016:49:12.

24. Zhu ZB, Yu MM, Chen YH, Guo QS, Zhang LX, Shi HZ, et al. Effects of ammonium to nitrate ratio on growth, nitrogen metabolism, photosynthetic efficiency and bioactive phytochemical production of Prunella vulgaris. Pharm Biol. 2014;52(12):1518-25.

25. Yu MM, Chen YH, Zhu ZB, Liu L, Zhang LX, Guo QS. Effect of phosphorus supply on plant productivity, photosynthetic efficiency and bioactivecomponent production in Prunella vulgaris L. under hydroponic condition. J Plant Nutr. 2016;39(12):1672-80.

26. Fazal $\mathrm{H}$, Abbasi BH, Ahmad N, Ali SS, Akbar F, Kanwal F Correlation of different spectral lights with biomass accumulation and production of antioxidant secondary metabolites in callus cultures of medicinally important Prunella vulgaris L. J Photoch Photobio B. 2016;159:1-7.

27. Zhu PJ, Yang L. Ambient UV-B radiation inhibits the growth and physiology of Brassica napus L. on the Qinghai-Tibetan plateau. Field Crop Res. 2015;171:79-85.

28. Takahashi S, Milward SE, Yamori W, Evans JR, Hillier W, Badger MR. The solar action spectrum of photosystem II damage. Plant Physiol. 2010;153:988-93.

29. Rai R, Meena RP, Smita SS, Shukla A, Rai SK, Pandey-Rai S. UV-B and UV-C pre-treatments induce physiological changes and artemisinin biosynthesis in Artemisia annua L. - an antimalarial plant. J Photochem Photobiol B. 2011;105(3):216-25.

30. Feild TS, Lee DW, Holbrook NM. Why leaves turn red in autumn. The role of anthocyanins in senescing leaves of red-osier dogwood. Plant Physiol. 2001;127:566-74 
31. Pal M, Sengupta UK, Srivastava AC, Jain V, Meena RC. Changes in growth and photosynthesis of mungbean induced by UV-B radiation. Indian J Plant Physiol. 1999;4(2):79-84.

32. Winkel-Sherley B. Biosynthesis of flavonoids and effects of stress. Curr Opin Plant Biol. 2002;5(3):218-23.

33. Kataria S, Jajoo A, Guruprasad KN. Impact of increasing ultraviolet-B (UV-B) radiation on photosynthetic processes. J Photochem Photobiol B. 2014;137:55-66.

34. Martínez-Lüscher J, Sanchez-Díaz M, Delrot S, Aguirreolea J, Pascual I, Gomès E. Ultraviolet-B radiation and water deficit interact to alter flavonol and anthocyanin profiles in grapevine berries through transcriptomic regulation. Plant Cell Physiol. 2014;55(11):1925-36.

35. Costa H, Gallego SM, Tomaro ML. Effect of UV-B radiation on antioxidant defense system in sunflower cotyledons. Plant Sci. 2002;162(6):939-45.

36. Vuleta A, Jovanović SM, Tucić B. Adaptive flexibility of enzymatic antioxidants SOD, APX and CAT to high light stress: the clonal perennial monocot Iris pumila as a study case. Plant Physiol Biochem. 2016;100:166-73.

37. Aravind P, Prasad MNV. Modulation of cadmium-induced oxidative stress in Ceratophyllum demersum by zinc involves ascorbate-glutathione cycle and glutathione metabolism. Plant Physiol Bioch. 2005;43(2):107-16.

38. Zhang PY, Yu J, Tang XX. UV-B radiation suppresses the growth and antioxidant systems of two marine microalgae, Platymonas subcordiformis (Wille) Hazen and Nitzschia closterium (Ehrenb.) W. Sm. J Integr Plant Biol. 2005;47(6):683-91.

39. Berli FJ, Moreno D, Piccoli P, Hespanhol-Vinna L, Silva MF, Bressan-Smith $R$, et al. Abscisic acid is involved in the response of grape (Vitis vinifera $L$.) cv. Malbec leaf tissues to ultraviolet-B radiation by enhancing ultravioletabsorbing compounds, antioxidant enzymes and membrane sterols. Plant Cell Environ. 2010;33(1):1-10.

40. Gao Q, Zhang LX. Ultraviolet-B-induced oxidative stress and antioxidant defense system responses in ascorbate-deficient vtc1 mutants of Arabidopsis thaliana. J Plant Physiol. 2008;165(2):138-48.

41. Kadur G, Swapan B, Sunita K, Sanjeev Y, Arjun T, Sanjay B, et al. Growth enhancement of soybean (Glycine max) upon exclusion of UV-B and UV-B/A components of solar radiation: characterization of photosynthetic parameters in leaves. Photosynth Res. 2007;94:299-306.

42. Interdonato R, Rosa M, Nieva CB, Gonzalez JA, Hilal M, Prado FE. Effects of low UV-B doses on the accumulation of UV-B absorbing compounds and total phenolics and carbohydrate metabolism in the peel of harvested lemons. Environ Exp Bot. 2011;70(2-3):204-11.

43. Keunen ELS, Peshev D, Vangronsveld J, Ened WVD, Cuypers A. Plant sugars are crucial players in the oxidative challenge during abiotic stress: extending the traditional concept. Plant Cell Environ. 2013;36(7):1242-55.

44. Wu XL, Yuan J, Luo AX, Chen Y, Fan YJ. Drought stress and re-watering increase secondary metabolites and enzyme activity in dendrobium moniliforme. Ind Crop Prod. 2016:94:385-93.

45. Fedina I, Georgieva K, Velitchkova M, Grigorova I. Effect of pretreatment of barley seedlings with different salts on the level of UV-B induced and UV-B absorbing compounds. Environ Exp Bot. 2006:56(3):225-30.

46. Takshak S, Agrawal SB. Defence strategies adopted by the medicinal plant Coleus forskohlii against supplemental ultraviolet-B radiation: augmentation of secondary metabolites and antioxidants. Plant Physiol Biochem. 2015:97:124-38.

47. Sharma P, Jha AB, Dubey RS, Pessarakli M. Reactive oxygen species, oxidative damage, and antioxidative defense mechanism in plants under stressful conditions. J Bot. 2012;2012:1-26.

48. Osakabe N, Takano H, Sanbongi C, Yasuda A, Yanagisawa R, Inoue K, et al. Anti-inflammatory and anti-allergic effect of rosmarinic acid (RA); inhibition of seasonal allergic rhinoconjunctivitis (SAR) and its mechanism. BioFactors. 2004;21(1-4):127-31.

49. Škottová N, Kazdová L, Oliyarnyk O, Večeřa R, Sobolová L, Ulrichová J. Phenolics-rich extracts from Silybum marianum and Prunella vulgaris reduce a high-sucrose diet induced oxidative stress in hereditary hypertriglyceridemic rats. Pharmacol Res. 2004;50(2):123-30.

50. Turunen M, Heller W, Stich S, Sandermann H, Sutinen ML, Norokorpi Y. The effects of UV exclusion on the soluble phenolics of young Scots pine seedlings in the subarctic. Environ Pollut. 1999;106(2):219-28.

51. Inostroza-Blancheteau C, Acevedo P, Loyola R, Arce-Johnson P, Alberdi M, Reyes-Diaz M. Short-term UV-B radiation affects photosynthetic performance and antioxidant gene expression in highbush blueberry leaves. Plant Physiol Bioch. 2016;107:301-9.
52. Zhu ZB, Liang ZS, Han RL. Saikosaponin accumulation and antioxidative protection in drought-stressed Bupleurum chinense DC. plants. Environ Exp Bot. 2009;66(2):326-33

53. Zhang GW, He L, Hu MM. Optimized ultrasonic-assisted extraction of flavonoids from Prunella vulgaris L. and evaluation of antioxidant activities in vitro. Innov. Food Sci Emerg Technol. 2011;12(1):18-25.

54. Sun MY, Gu XD, Fu HW, Zhang L, Chen RZ, Cui L, et al. Change of secondary metabolites in leaves of Ginkgo biloba L. in response to UV-B induction. Innov Food Sci Emerg Technol. 2010;11(4):672-6.

55. Zu YG, Pang HH, Yu JH, Li DW, Wei XX, Gao YX, et al. Responses in the morphology, physiology and biochemistry of Taxus chinensis var. mairei grown under supplementary UV-B radiation. J Photochem Photobiol B. 2010;98(2):152-8.

56. Leon-Felix J. Low temperature and ultraviolet-B radiation affect chlorophyll content and induce the accumulation of UV-B-absorbing and antioxidant compounds in bell pepper (Capsicum annuum) plants. Environ Exp Bot. 2017;139:143-51.

57. Sánchez-Campillo M, Gabaldon JA, Castillo J, Benavente-García O, Del Baño MJ, Alcaraz M, et al. Rosmarinic acid, a photo-protective agent against UV and other ionizing radiations. Food Chem Toxicol. 2009;47(2):386-92.

58. Han RB, Yuan YJ. Oxidative burst in suspension culture of Taxus cuspidata induced by a laminar shear stress in short-term. Biotechnol Progr. 2004;20(2):507-13.

59. Strazzer P, Guzzo F, Levi M. Correlated accumulation of anthocyanins and rosmarinic acid in mechanically stressed red cell suspensions of basil (Ocimum basilicum). J Plant Physiol. 2011;168(3):288-93.

60. Feng $L$, Jia $X B$, Zhu MM, Chen $Y$, Shi F. Antioxidant activities of total phenols of Prunella vulgaris L. Vitro and in tumor-bearing mice. Molecules. 2010;15(12):9145-56

61. Raafat K, Wurglics M, Schubert-Zsilavecz M. Prunella vulgaris L. active components and their hypoglycemic and antinociceptive effects in alloxan-induced diabetic mice. Biomed Pharmacother. 2016;84:1008-18.

62. Luthria DL, Mukhopadhyay S, Krizek DT. Content of total phenolics and phenolic acids in tomato (Lycopersicon esculentum Mill.) fruits as influenced by cultivar and solar UV radiation. J. Food Compos Anal. 2006;19(8):771-7.

63. Piao MJ, Kang KA, Zhang R, Ko DO, Wang ZH, You HJ, et al. Hyperoside prevents oxidative damage induced by hydrogen peroxide in lung fibroblast cells via an antioxidant effect. Biochim Biophys Acta. 2008;1780(12):1448-57.

64. Cirak C, Radusiene J, Jakstas V, Ivanauskas L, Seyis F, Yayla F. Altitudinal changes in secondary metabolite contents of Hypericum androsaemum and Hypericum polyphyllum. Biochem Syst Ecol. 2017;70:108-15.

65. Choi JH, Kim DW, Yun N, Choi JS, Islam MN, Kim YS, et al. Protective effects of hyperoside against carbon tetrachloride-induced liver damage in mice. J Nat Prod. 2011;74(5):1055-60.

66. Chen LZ, Wang GH, Hong S, Liu A, Li C, Liu YD. UV-B-induced oxidative damage and protective role of exopolysaccharides in desert cyanobacterium Microcoleus vaginatus. J Integr Plant Biol. 2009;51(2):194-200.

67. Herndl GJ, Muller-Niklas G, Frick J. Major role of ultraviolet-B in controlling bacterioplankton growth in the surface layer of the ocean. Nature. 1993:361:717-9.

68. Müller-Niklas G, Heissenberger A, Puskaric S, Herndl GJ. Ultraviolet-B radiation and bacterial metabolism in coastal waters. Aquat Microbial Ecol. 1995;9(2):111-6.

69. Garde K, Gustavson K. The impact of UV-B radiation on alkaline phosphatase activity in phosphorus-depleted marine ecosystems. J Exp Mar Biol Ecol. 1999;238(1):93-105.

70. Martin-Aragón S, De Las Heras B, Sanchez-Reus MI, Benedi J. Pharmacological modification of endogenous antioxidant enzymes by ursolic acid on tetrachloride-induced liver damage in rats and primary cultures of rat hepatocytes. Exp Toxicol Pathol. 2001;53(2-3):199-206.

71. Shyu MH, Kao TC, Yen GC. Hsian-tsao (Mesona procumbens Heml.) prevents against rat liver induced by $\mathrm{CCl}_{4}$ via inhibition of hepatic stellate cells activation. Food Chem Toxicol. 2008;46(12):3707-13.

72. Grassmann J, Hippeli S, Elstner EF. Plant's defence and its benefits for animals and medicine: role of phenolics and terpenoids in avoiding oxygen stress. Plant Physiol Bioch. 2002;40(6-8):471-8. 
73. Zainol MK, Abd-Hamid A, Yusof S, Muse R. Antioxidative activity and total phenolic compounds of leaf, root and petiole of four accessions of Centella asiatica (L.) Urban. Food Chem. 2003;81(4):575-81.

74. Król A, Amarowicz R, Weidner S. Changes in the composition of phenolic compounds and antioxidant properties of grapevine roots and leaves (Vitis vinifera L.) under continuous of long-term drought stress. Acta Physiol Plant. 2014;36(6):1491-9.
75. Rosicka-Kaczmarek J. Polifenole jako naturalne antyoksydanty w zywnosci. Przeg Piek Cuk. 2004;52(6):12-6.

76. Xu C, Zang Y, Cao L, Lu J. Phenolic compounds and antioxidant properties of different grape cultivars grown in China. Food Chem. 2010;119(4):1557-65.
Ready to submit your research? Choose BMC and benefit from:

- fast, convenient online submission

- thorough peer review by experienced researchers in your field

- rapid publication on acceptance

- support for research data, including large and complex data types

- gold Open Access which fosters wider collaboration and increased citations

- maximum visibility for your research: over $100 \mathrm{M}$ website views per year

At BMC, research is always in progress.

Learn more biomedcentral.com/submissions 